\title{
The effects of service quality on international tourist satisfaction and loyalty: Insight from Vietnam
}

\author{
Kim Chi Nguyen Thi ${ }^{a^{*}}$, Tung Le Huy ${ }^{a}$, Chung Hoang Van ${ }^{b}$ and Phong Cao Tuan ${ }^{c}$
}

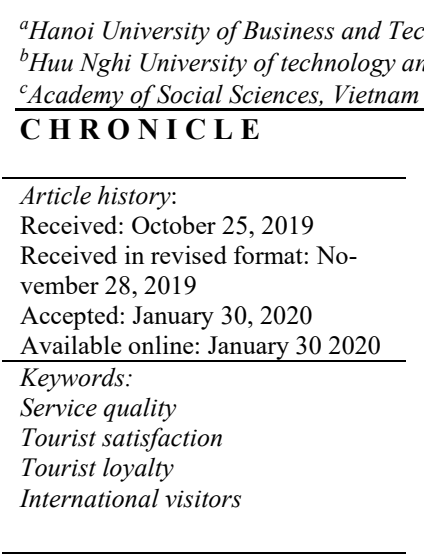

\begin{abstract}
A B S T R A C T
This study focuses on investigating the relationship between tourist quality service, satisfaction and loyalty among international visitors who came to Vietnam. Specifically, this research also aims to discover the mediating effects of tourist satisfaction on the relationship between tourist quality service and loyalty (revisit and recommend to others). By using the data collected from 516 international visitors who travelled in Vietnam, authors use a meta-analytic path analysis to show that only two factors of tourist quality service had significant effects on tourist satisfaction and loyalty, including tangibles and responsiveness. Moreover, tangibles and responsiveness not only had direct effects, but they also they had some indirect impacts on tourist loyalty throughout tourist satisfaction. Interestingly, the relationship between tourist satisfaction and their loyalty was strongest.
\end{abstract}

\section{Introduction}

The context of the tourism boom and the competition among destinations have been serious obstacles for tourism planners. In particular, the Resolution No.08/ NQ - TTg issued by the Political Bureau, determined tourism as a spearhead industry in Vietnam's socioeconomic development that has been increasingly facilitating all provinces developing tourism activities. Therefore, local areas gradually identify its advantages in terms of tourism resources to exploit and invest. They also orient the tourism service as the main sector of economic activities in the region. This leads to the fact that destination market has become more competitive, pressurizing into the number of tourist arrivals for each place. Unquestionably, tourist satisfaction is the key competitive advantages. If tourists are satisfied with the image, the recommendation intention and repeat visitation towards that destination will be created (Hui et al., 2007; Osti et al., 2012). Practically, service quality is the golden key to open the satisfaction door for tourists. Thus, the process by which customers evaluate a purchase, thereby determining satisfaction and likelihood of repurchase, is important for all marketers (Hudson et al., 2004). It not only brings benefits in 
terms of revenue but also creates a reputable image for a company or a destination (Osti et al., 2012; Aliman, 2014; Castro et al., 2017). This is a push factor for building destination brand because both help differentiating services or products in the fierce market competition.

Based on this sense, this study aims to identify tourist's satisfaction and loyalty through SERVQUAL model. Specially, this paper examines the effects of service quality (all variables of SERVQUAL model, including tangible, reliability, responsiveness, assurance and empathy) on tourist's satisfaction and loyalty among visitors who came to Vietnam.

\section{Literature review}

\subsection{Tourism Service Quality}

In the competitive market as nowadays, the requirement of service quality has been an important task for marketers to serve consumers. According to Lewis and Boom (1983), service quality is a tool to measure the gap between the delivered service and customer expectations. Grönroos (1984, p.37) defines service quality as "the outcome of an evaluation process where the consumer compares his expectations with the service he perceived". In line with this thinking, Parasuraman et al. (1985) developed the conceptual framework of service quality to prove that "quality is a comparison between expectations and performance", which leads to the customer's satisfaction. To agree with this notion, Gržinić and Jasmina (2007) conceptualized service quality as a way to control business process to make sure total satisfaction to the consumer on all levels, leading to an increase of competitive advantage of the entire company. Therefore, Atilgan et al. (2003) posited that service quality measurement is the key subject of several empirical and conceptual researches in the field of service marketing. In the tourism industry, service quality is also assessed as a crucial component to differentiate service products as well as to build a competitive advantage (Hudson et al., 2004). Today, some tourism researchers apply the SERVQUAL model in recognizing not only the drawback factors that must be improved but also the strength components that have to enhance. In other words, SERVQUAL model plays a fundamental role in analyzing the potential for tourism development of a destination. Pawitra and Tan (2003) used SERVQUAL to identify the image of Singapore from the perspective of tourists from Indonesia. Consequently, key strengths and weaknesses were determined. Because of its effectiveness, Atilgan et al. (2003) constructed the map that shows the main variables in the tourism field, Hudson et al. (2004) discovered key characteristics in tour operating sector and Gržinić (2007) explored important features in hotel industry.

Generally, SERVQUAL model is an instrument developed by Parasuraman, Zeithaml and Berry (1988), which focuses on the notion of perceived quality. Although, there are some criticisms about the model in terms of the nature and number of dimensions (Finn \& Lamb, 1991; Cronin \& Taylor, 1992), SERVQUAL is evaluated as a concise scale, easy to use by managers (Buttle,1996). The model consists of five major dimensions: tangible, reliability, responsiveness, assurance and empathy. First, "tangible" represents the appearance of physical facilities, equipment and personnel. "Reliability" is generally defined as the ability to perform the promised service dependably and accurately. "Responsiveness" is the willingness to help customers and to provide prompt service. "Assurance" covers the knowledge and courtesy of employees and their ability to convey trust and confidence. The last dimension, "Empathy" is defined as the provision of care, and the paying of individualized attention to customers.

\subsection{Tourist Satisfaction}

In the competitive destination market, the customer's satisfaction is truly important, it not only has influenced the performance of services or products but also establishes the belief in service providers, which leads to the intention to revisit or recommend to others. Therefore, providing high quality service and ensuring customer satisfaction are widely accepted as the key factors bringing to the success of the tourism sectors (Hui et al., 2007). In addition, exceptional service quality is a source of differentiation 
and competitive advantage (Mcquilken et al., 2000). Generally, tourist's satisfaction towards a destination is seen as an individual's assessment levels with the service performance that exceeds his or her expectations (Tribe \& Snaith, 1998; Sukiman et al., 2013). Previously, Woodside, Frey and Daly (1989) also considered tourist's satisfaction as a post-purchase construct that is related to how much a consumer likes or dislikes a service or product after experiencing or consuming it. For instance, after the trip, tourists give their feedback by their communication tools such as word of mouth or social media. It may be a positive comment, but it also may be a negative complaint that impacts the image of a destination. Thus, having a deeper insight what drives satisfaction for a tourist is one of the most relevant areas of research for the tourism industry (Prebensen, 2006). According to Armario (2008), there are multiple dimensions when evaluating the degree of tourist satisfaction, including the expectations generated before and during the trip, as well as the tourist's perception of the service received. In other words, it reflects both a cognitive and an affective phenomenon. This is why many marketing investigating the tourist behaviors and using SERVQUAL model to assess the level of tourist satisfaction with a destination. Taken together with found attribute images of Echtner and Richie (2003), the perceived service quality of a given place will be evaluated in details. Based on this foundation, five hypotheses are proposed as following:

$\mathrm{H}_{1}$. The tourist's overall satisfaction is positively related to the tangible characteristics of Vietnam.

$\mathrm{H}_{2}$. The tourist's overall satisfaction is positively related to the reliability characteristics of Vietnam.

$\mathrm{H}_{3}$. The tourist's overall satisfaction is positively related to the responsiveness characteristics of Vietnam.

$\mathrm{H}_{4}$ The tourist's overall satisfaction is positively related to the assurance characteristics of Vietnam.

$\mathrm{H}_{5}$. The tourist's overall satisfaction is positively related to the empathy characteristics of Vietnam.

\subsection{Tourist Loyalty}

The correlation between loyalty and satisfaction is fairly well considered (Conlon \& Murray, 1996). However, it is not entirely symmetrical because of the following reasons. Firstly, loyal customers tend to be satisfied, but satisfaction does not always transform into loyalty (Wojnarowska, 2005). Secondly, a satisfied customer is not always become a loyal one, while dissatisfaction does not necessarily involve in the lack of loyalty (Otto, 2004). Perhaps this result from the fact that loyalty may also be influenced by other factors than satisfaction. Loyalty towards a travel agency, destination or international visitor attraction is seen as one of the main indicators of the success of marketing strategy in tourist field (Flavian et al., 2001) and represents one of the important axioms in tourism management (Getty \& Thomson, 1994). Loyal visitors are much more resistant to competitors, as they believe their current destination branding will be likely to satisfy their expectations like no other. Repurchase intention is determined as the customer's decision to take part in future activities with a service provider (Hui et al., 2007). In the tourism sectors, this takes form of a repurchase of tourism services or a revisit of a destination or visitor attraction (Mawa, 2018). Revisit intentions do not necessarily infer loyalty towards an attraction; they might basically result from mere force of habit or the lack of other alternatives. However, they show a more reliable indicator of future behavior than satisfaction or the perception of product quality. During the trip, service quality significantly affects a customer's behavior; in which the image of friendly local people partly changes a customer's attitude. Consequently, they form an affective image about that destination, leading to the intention to revisit. San Martín and Del Bosque (2008, p.266) stated "a relationship between psychological motivations and affective images has been suggested in tourism research". After the trip, an overall image of a destination will be profoundly estimated by customer satisfaction, leading to the intention to recommend to others. As a result, destination image was spread expansively as the expectation of destination branding planners. Studies within the tourism sector confirm the correlation between tourist satisfaction and their revisit intentions, presenting that satisfied customers are more inclined to loyalty towards the provider and to repurchase intentions. Advantages of a loyal base of returning visitors consists of a chance to lower marketing expenses, a growth in sales and attendance and a 
reduction of operating costs. Moreover, loyal visitors need less information and themselves play the role as a source of information for others. As a result, the following hypotheses are proposed to test the relationship between perceived serviced quality and tourist's loyalty and the correlation between the tourist satisfaction and their loyalty.

$\mathrm{H}_{6}$. The tourist's loyalty is positively related to the tangible characteristics of Vietnam.

$\mathrm{H}_{7}$. The tourist's loyalty is positively related to the reliability characteristics of Vietnam.

$\mathrm{H}_{8}$. The tourist's loyalty is positively related to the empathy characteristics of Vietnam.

H9. The tourist's loyalty is positively related to the responsiveness characteristics of Vietnam.

$\mathrm{H}_{10}$. The tourist's loyalty is positively related to the assurance characteristics of Vietnam.

$\mathrm{H}_{11}$. The tourist's loyalty is positively related to their overall satisfaction.

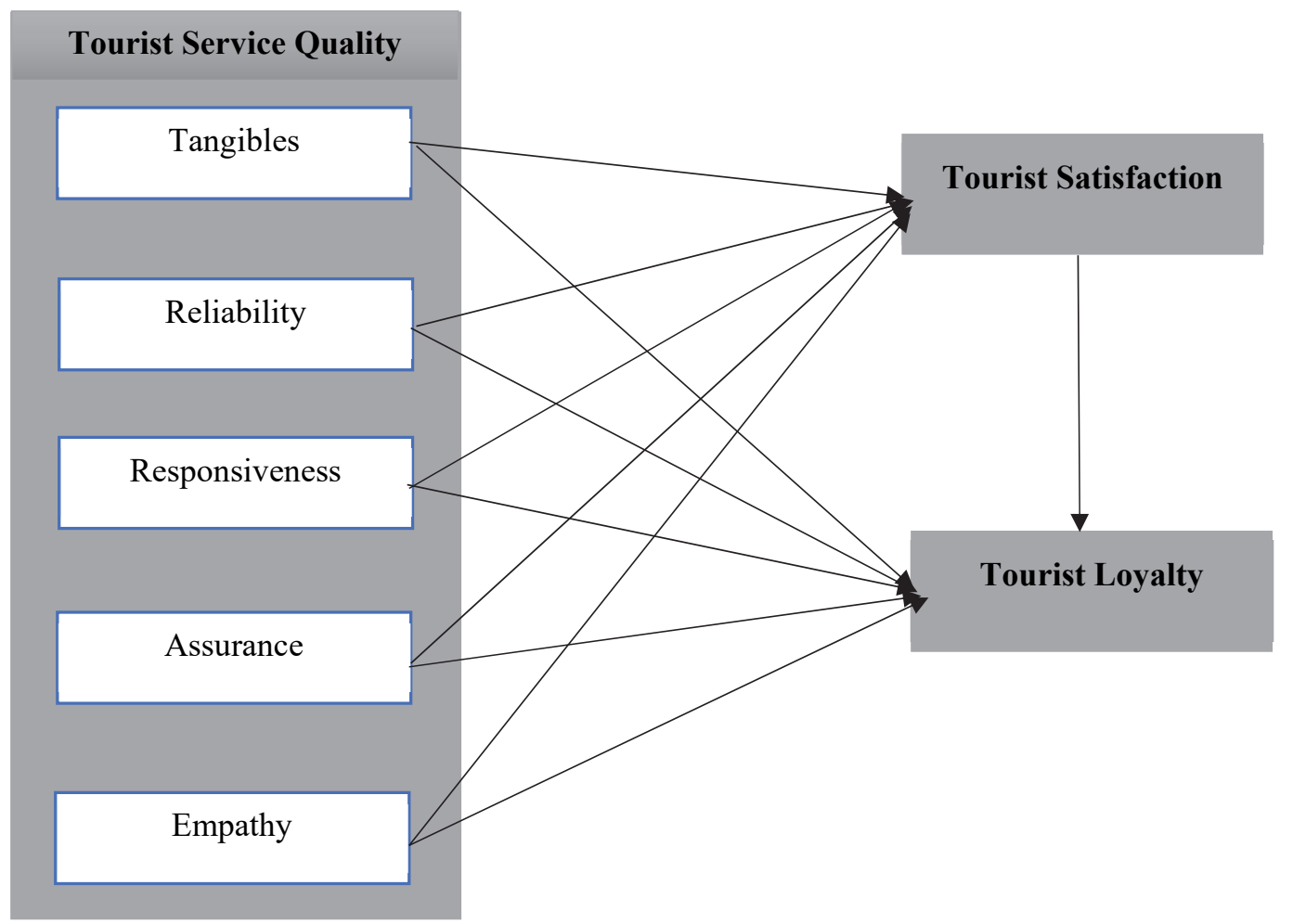

Fig. 1. Research Framework

\section{Methodology}

Surveyed subjects: international tourists traveling in Da Nang, Sapa and Ha Long Bay were randomly selected.

Sample size: 600 questionnaires (200 questionnaires in each places) were distributed into international visitors who travelled in Vietnam, but only 516 questionnaires were fully answered and enough conditions for analysing.

Questionnaires: The content of the question in the questionnaire allows international visitors providing their opinions in terms of demographic information and the related observable variables. The measures are coded by the Likert scale of 5 points (1: Strongly disagreed, 2: Disagreed, 3: Neutral, 4: Agreed and 5: Strongly Agreed).

Survey time: May to September, 2019 
Table 1

Demographic information of international visitors

\begin{tabular}{llll}
\hline Demographic information & & Frequency & Percent (\%) \\
\hline Gender & Male & 284 & 55.0 \\
& Female & 232 & 45.0 \\
\hline Marital Status & Single & 190 & 36.8 \\
& Married & 326 & 63.2 \\
\hline \multirow{2}{*}{ Age (years old) } & Under 25 & 227 & 44.0 \\
& $25-35$ & 158 & 30.6 \\
\cline { 2 - 4 } & $36-45$ & 97 & 18.8 \\
& Over 46 & 34 & 6.6 \\
\hline Education & High School & 91 & 17.6 \\
& University/College & 384 & 74.4 \\
& Post-Graduate & 41 & 8.0 \\
\hline Total & & 516 & 100 \\
\hline Source: Authors' elaborations based on research study & &
\end{tabular}

Data analysis methods: Author performed a regression analysis to assess the contributions of perceived service quality to tourist satisfaction and their loyalty as well. Structural equation modelling (SEM) was implemented to test the hypothesized relationships and analysis process includes three main steps. First, Cronbach's alpha and explorative factor analysis (EFA) are implemented to assess the reliability of variables. Secondly, confirmatory factor analysis (CFA) is employed to test the empirical validity of the research model and each measure. Finally, the structural equation modelling was then applied to estimated path coefficients for each proposed relationship in the conceptual framework. In addition, the statistical analysis has been carried out using SPSS 22.0 and AMOS 22.0 software.

\section{Results}

\subsection{Test for the reliability of the scales}

As seen in the Table 2, all the Corrected Item-Total Correlation coefficients of the observed variables are higher than 0.3 , so 33 observable variables are of good quality. On the other hand, all the scales have the Cronbach's Alpha over 0.6, so all factors meet the quality requirements or reliability requirements for inclusion in the EFA analysis. Table 3 also shows that KMO is $0.809>0.5$, the EFA is appropriate with the data set. Bartlett's test has $\mathrm{df}=561$ with statistical significance level $=0.000<0.05$, so the observed variables have a linear correlation with the representative factors. Therefore, data is appropriate for EFA. Moreover, the cumulative variance value is $63.137(\%)$ in the Cumulative columns. This means that 63.137 of the change in these seven factors is explained by their observational variables. The eigenvalue of every factor is higher than 1 confirming that these factors are very good summaries of their observed variables. The observed variables have Factor loading over 0.5 shows that the correlation coefficient between each observation variable and each representative factor is relatively close to tight.

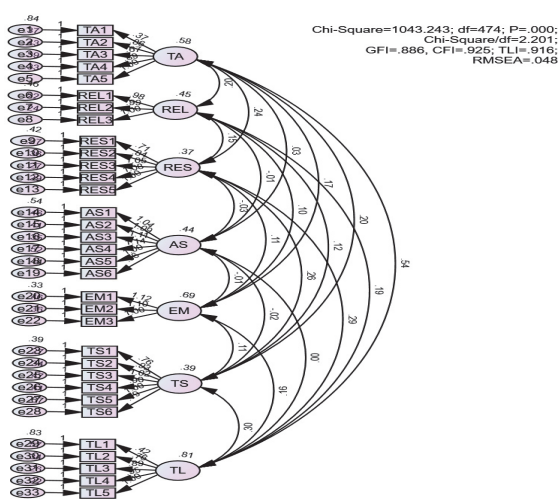

Fig. 2. The results of confirmatory factor analysis Source: Authors' elaborations based on research study

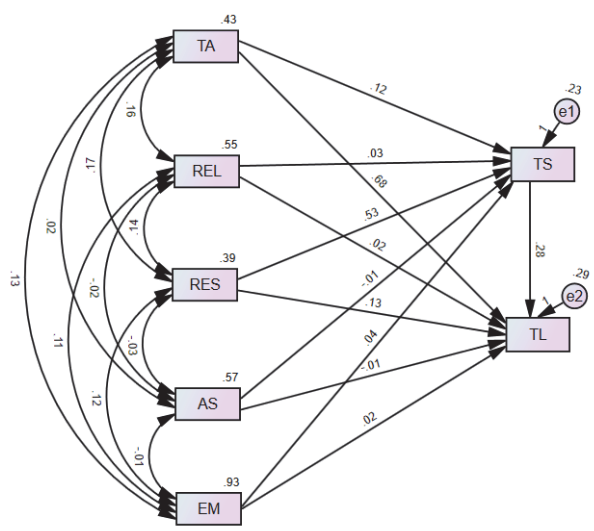

Fig. 3. The results of structural path analyses 
Table 2

The reliability of variables

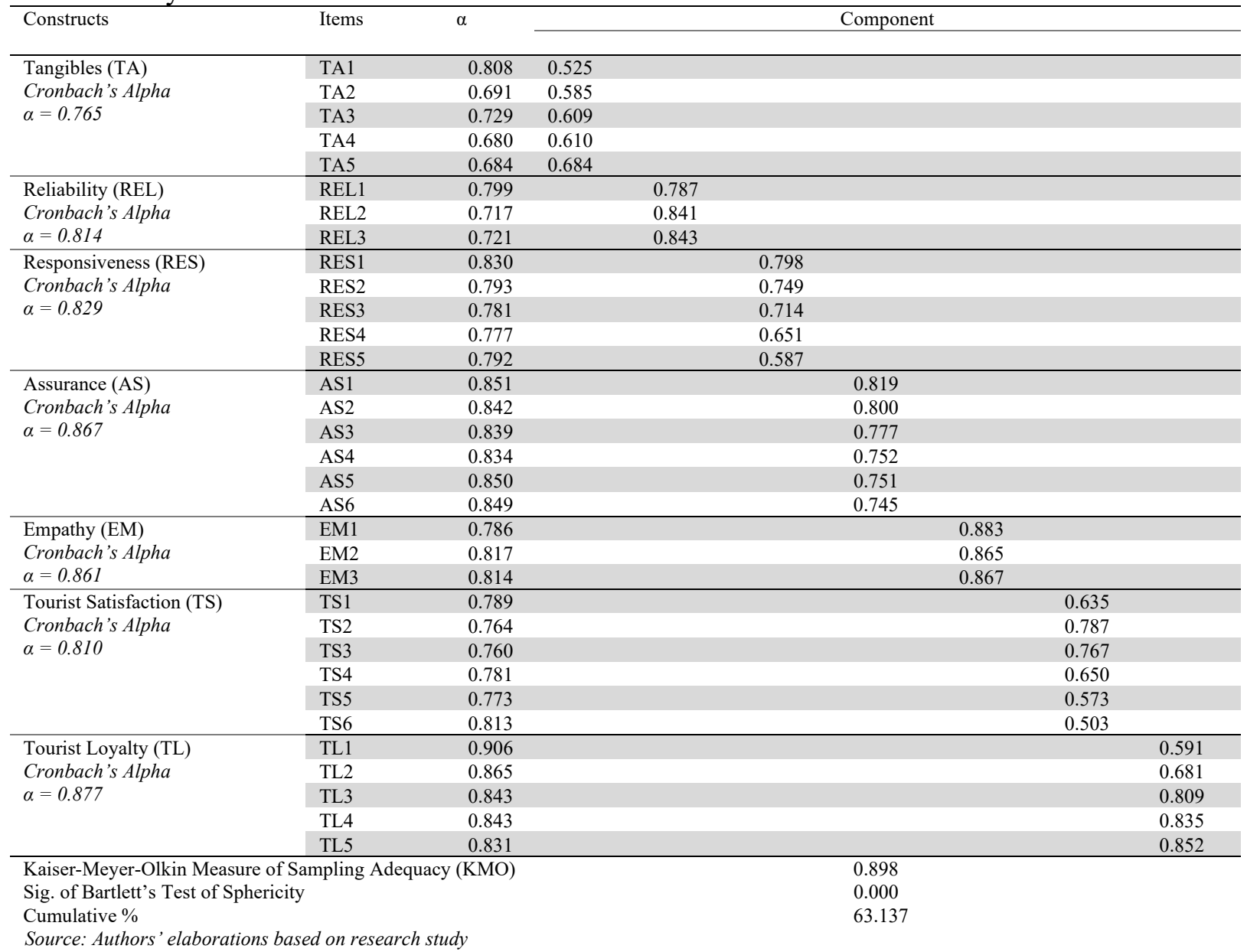

In addition, the confirmatory factor analysis (CFA) is performed to test the model fit and the validity of scales through using AMOS 22.0 (Hair et al.,1988). The results generally show a good level of fit for the measurement models. After assessing each construct, the full measurement model was analysed at Fig. 2. The results of CFA indicate a reasonably good level of fit: $\chi^{2}(474)=1043.243, p=0.000, \mathrm{CMIN} / \mathrm{df}$ $=2.201$ (Kettinger et al., 1995), GFI $=0.925$, TLI $=0.916>0.9$ (Bentler \& Bonnett, 1980), RMSEA $=$ 0.048 . Also, standardized regression weights of all items are higher than $0.5(\lambda>0.5)$. Thus, the convergent validity is determined at all scales.

\subsection{Structural and meta-analytic path analyses}

The path coefficients in the structural equation modelling (SEM) analyses are shown in Fig. 3. The results of the hypothesis testing are summarized in Table 3 . Table 3 shows that hypothesis $\mathrm{H}_{1}$ is supported, since tangible has a positive impact on tourist satisfaction $(\beta=0.119 ; p$-value $<0.01)$. On the other word, this study indicates reliability has the strongest effect on tourist satisfaction $(\beta=0.525$; $p$-value $<0.001)$. Moreover, the results of the study illustrate that the relationship between tangibles and tourist loyalty is very strong $(\beta=0.679$; $p$-value $<0.000)$, following by the link between responsiveness and tourist loyalty $(\beta=0.126 ; p$-value $<0.05)$. Interestingly, the strongest correlation between tourist satisfaction and their loyalty is proved $(\beta=0.679 ; p$-value $<0.000)$. Thus, the research results show that only two factors of tourist service quality in the SERVQUAL model have impacts on tourist satisfaction, including tangibles and responsiveness. Analogously to the relationship between tourist service quality and tourist loyalty, there are just two factor of tourist service quality affecting tourist loyalty, including responsiveness and tangibles. Interestingly, the relationship between tourist satisfaction and tourist loyalty is strongest. In terms of the mediating role of tourist satisfaction between tourist service quality and tourist loyalty, 
the study indicates that tangibles and responsiveness not only have the direct effect, but they also indirectly influence on tourist loyalty throughout tourist satisfaction $\left(\beta_{\text {indirect } R E S-T L}=0.146, \mathrm{p}<0.000 ; \beta_{\text {indirect }}\right.$ $T A-T L=0.033, \mathrm{p}<0.000$ ). In other word, the tourist satisfaction plays the mediating role in the link between tangibles, responsiveness and tourist loyalty.

Table 3

The results of testing the research hypotheses

\begin{tabular}{|c|c|c|c|c|c|c|c|c|}
\hline \multicolumn{4}{|c|}{ Hypotheses } & \multirow{2}{*}{$\begin{array}{c}\text { Estimate } \\
0.119\end{array}$} & \multirow{2}{*}{$\begin{array}{c}\text { S.E } \\
0.037\end{array}$} & \multirow{2}{*}{$\begin{array}{c}\text { C.R } \\
3.192\end{array}$} & \multirow{2}{*}{$\begin{array}{c}\mathbf{P} \\
0.001\end{array}$} & \multirow{2}{*}{$\begin{array}{c}\text { Conclusion } \\
\text { Supported }\end{array}$} \\
\hline $\mathrm{H} 1$ & TA & $\rightarrow$ & TS & & & & & \\
\hline $\mathrm{H} 2$ & REL & $\rightarrow$ & TS & 0.028 & 0.031 & 0.884 & 0.377 & Rejected \\
\hline H3 & RES & $\rightarrow$ & TS & 0.525 & 0.039 & 13.595 & $* * *$ & Supported \\
\hline $\mathrm{H} 4$ & AS & $\rightarrow$ & TS & -0.011 & 0.028 & -0.378 & 0.705 & Rejected \\
\hline $\mathrm{H} 5$ & EM & $\rightarrow$ & TS & 0.038 & 0.023 & 1.654 & 0.098 & Rejected \\
\hline H6 & TA & $\rightarrow$ & $\mathrm{TL}$ & 0.679 & 0.042 & 16.281 & $* * *$ & Supported \\
\hline $\mathrm{H} 7$ & REL & $\rightarrow$ & $\mathrm{TL}$ & 0.025 & 0.035 & 0.713 & 0.476 & Rejected \\
\hline H8 & RES & $\rightarrow$ & $\mathrm{TL}$ & 0.126 & 0.05 & 2.531 & 0.011 & Supported \\
\hline $\mathrm{H} 9$ & AS & $\rightarrow$ & $\mathrm{TL}$ & -0.008 & 0.031 & -0.267 & 0.79 & Rejected \\
\hline $\mathrm{H} 10$ & EM & $\rightarrow$ & $\mathrm{TL}$ & 0.02 & 0.025 & 0.787 & 0.431 & Rejected \\
\hline H11 & TS & $\rightarrow$ & $\mathrm{TL}$ & 0.277 & 0.049 & 5.682 & $* * *$ & Supported \\
\hline
\end{tabular}

\section{Conclusion}

This study has been expected to contribute to tourist literature in the following perspectives. Firstly, within five factors of tourist service quality in the SERVQUAL model only tangibles and responsiveness have had direct influences on both tourist satisfaction and tourist loyalty. Secondly, tangibles and responsiveness not only affect directly, but they also had indirect effects on tourist loyalty throughout tourist satisfaction. Finally, this study proves that the relationship between tourist satisfaction and their loyalty was very strong. Thus, in order to promote tourist loyalty (revisit and recommend to others) and the satisfaction of visitors, the government should set some policies to enhance the tourist service quality.

\section{References}

Aliman, N. K., Hashim, S. M., Wahid, S. D. M., \& Harudin, S. (2014). Tourist expectation, perceived quality and destination image: Effects on perceived value and satisfaction of tourists visiting langkawi Island, Malaysia. Asian Journal of Business and Management, 2(3).

Armario, E. (2008). Tourist satisfaction: an analysis of its antecedents. Universidad, Sociedady Mercados Globales, 3(6),73-82

Bentler, P. M., \& Bonett, D. G. (1980). Significance tests and goodness of fit in the analysis of covariance structures, Psychological Bulletin, 88(3), 588.

Buttle, F. (1996). SERVQUAL: review, critique, research agenda. European Journal of Marketing, $30(1), 833$

Castro, J. C, Quisimalin, M., de Pablos, C., Gancino, V. \& Jerez, J. (2017). Tourism marketing: Measuring tourist satisfaction. Journal of Service Science and Management, 10, 2809-308

Cronin, J., \& Taylor, S. (1992). Measuring service quality: A reexamination and extension. Journal of Marketing, 56(3), 5568

Conlon, D. E. \& Murray, N.M. (1996). Customer perceptions of corporate responses to product complaints: the role of explanations. Academy of Management Journal, 39(4), 1040-1056.

Atilgan, E., Akinci, S., \& Aksoy, S. (2003). Mapping service quality in the tourism industry. Managing Service Quality: An International Journal, 13(5), 412422

Echtner, C. M., \& EchtnerBrent Ritchie, J.R. (2003), The meaning and measurement of destination image, The Journal of Tourism Studies, 14(1), 39-51

Flavian, C., Martinez, E., \& Polo, Y. (2001). Loyalty to grocery stores in the Spanish market of the 1990s. Journal of Retailing and Consumer Services, 8, 85-93.

Finn, D., \& Lamb, C. (1991), An evaluation of the SERVQUAL scales in a retailing setting. Advances in Consumer Research, 18, 48390 
Grönroos, C. (1984). A service quality model and its marketing implications. European Journal of Marketing, 18(4), 3644.

Gržinić, D. (2007). Concepts of service quality measurement in hotel industry. Concepts of Service Quality Measurement in Hotel Industry, 1, 81-98.

San Martín, H., \& Del Bosque, I. A. R. (2008). Exploring the cognitive-affective nature of destination image and the role of psychological factors in its formation. Tourism management, 29(2), 263-277.

Hui, T. K, Wan, D., \& Ho, A. (2007). Tourists' satisfaction, recommendation and revisiting Singapore. Tourism Management, 28, 965-975

Kettinger, W. J., Lee, C. C., \& Lee, S. (1995), Global measures of information service quality: a crossnational study. Decision sciences, 26(5), 569-588.

Lewis, R. C \& Bernard H. B. (1983). "The marketing aspects of service quality" in Emerging Perspective on Service Marketing, L. Berry, G. Shostack, and G. Upah, eds., Chicago: American Marketing, 99 107.

Mcquilken, L., Breth R., \& Shaw, R. N. (2000). Consumer expectation and satisfaction levels: An evaluation of tourism in the Otway Region. Proceedings by Bowater School of Management and Marketing. Deakin University, ANZMC.

Osti, L., Disegna, M., \& Brida, J. G. (2012). Repeat visits and intentions to revisit a sporting event and its nearby destinations. Journal of Vacation Marketing, 18(1), 61-75.

Parasuraman, A., Zeithaml, V.A., \& Berry, L. (1985). A conceptual model of service quality and its implications for future research. Journal of Marketing, 49(Fall), 41-50.

Parasuraman, A., Zeithaml, V. A., \& Berry, L. L. (1988). SERVQUAL: A multiple item scale for measuring consumer perceptions of service quality. Journal of Retailing, 64(1), 1237.

Prebensen, N. K. (2006). Segmenting the group tourist heading for warmer weather: A Norwegian example. Journal of Travel \& Tourism Marketing, 19(4), 27-40.

Hudson, S., Hudson, P., \& Miller, G. A. (2004). The measurement of service quality in the tour operating sector: a methodological comparison. Journal of travel Research, 42(3), 305-312.

Sukiman, M. F., Omar, S. I., Muhibudin, M., Yussof, I., \& Mohamed, B. (2013). Tourist satisfaction as the key to destination survival in Pahang. Procedia - Social and Behavioral Sciences, 91, 78-87

Pawitra, T. A., \& Tan, K. C. (2003). Tourist satisfaction in Singapore-a perspective from Indonesian tourists. Managing Service Quality: An International Journal, 13(5), 399-411.

Tribe, J., \& Snaith, T. (1998), From SERVQUAL to HOLSAT: Holiday satisfaction in Varadero, Cuba. Tourism Management, 19, 25-34.

Wojnarowska, H. (2005). Determinants of customer loyalty (Vol. 677, p. 86). Scientific Papers. Cracow University of Economics, 90.

Woodside, A. G., Frey, L. L., \& Daly, R. T. (1989), Linking service quality, customer satisfaction and behavioral intention, Journal of Health Care Marketing, 9(4), 5-17.

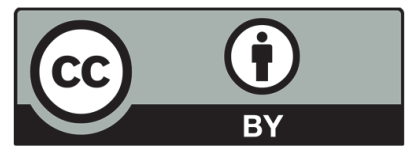

(C) 2020 by the authors; licensee Growing Science, Canada. This is an open access article distributed under the terms and conditions of the Creative Commons Attribution (CC-BY) license (http://creativecommons.org/licenses/by/4.0/). 